\title{
KAJIAN PERGERAKAN FLUIDA BAWAH PERMUKAAN BERDASARKAN ANALISIS RAPAT MASSA DAERAH PORONG SIDOARJO
}

\author{
EDDY SUPRIYANA * \\ Program Studi Geofisika - FMIPA Universitas Padjadjaran \\ Jl. Raya Bandung-Sumedang Km 21 Jatinangor, Sumedang 45363
}

\begin{abstract}
Abstrak. Daerah terdampak di sekitar radius tanggul lumpur Sidoarjo (LUSI), terutama di bagian Baratnya terjadi amblasan dan bualan gas yang keluar ke permukaan, hal ini diantaranya disebabkan adanya kekosongan rongga pada lapisan tanah di bawah permukaan yang diduga karena pergerakan massa lumpur di sekitar area tersebut sehingga kontruksi lapisannya tidak kuat menyangga beban yang ada di permukaan. Untuk dapat memprediksi arah gerakan lumpur dibawah permukaan, diperlukan studi geofisika yakni metoda gravity yang bersifat monitoring (time lapse) yang dikorelasikan dengan kajian geologi daerah tersebut. Pengamatan ini telah dilakukan di beberapa perioda tahun 2010 sampai dengan tahun 2011. Berdasarkan data medan gravitasi $(\Delta \mathrm{g})$ di beberapa perioda tersebut dengan spasi titik amat cukup rapat sehingga dengan menggunakan pendekatan empiris (Green's function) dapat diproses menjadi sebaran rapat massa $(\Delta \rho)$ di kedalaman tertentu. Hasil proses berupa peta sebaran densitas $(\Delta \rho)$ di kedalaman 1500 meter, diharapkan dapat menginformasikan beberapa zona yang terdampak dengan nilai densitas $(\Delta \rho)$ berkisar antara $1,1 \mathrm{gr} / \mathrm{cc}$ - 2,1 gr/cc dimana konturnya mengikuti pola cekungan Jawa Timur yang menunjukan nilai densitas rendah ke arah Utara ditempati oleh endapan laut dangkal dan cenderung nilai densitas tinggi menuju ke arah Selatan - Tenggara yang merupakan endapan volkanik (gunungapi).
\end{abstract}

Kata kunci : Lumpur Sidoarjo (LUSI), Monitoring, Gravity, Rapat massa

Abstract. Affected areas around the radius of the embankment mud (LUSI), especially in its Western happen subsidence and gas to the surface, it was partly due to a void cavity in the soil layer below the surface which is allegedly due to the movement of masses of mud around the area so layer construction is not strong to support the load on the surface. To be able to predict the direction of movement of mud below the surface, the method required gravity geophysical studies that are monitoring (time lapse) that correlated with geological study of the area. This observation has been made in some period of 2010 to 2011. Based on data of the gravitational field $(\Delta \mathrm{g})$ in some periods of the spaced points very short so by using an empirical approach (Green's function) can be processed into the distribution of mass density $(\Delta \rho)$ in certain depth. The process results in the form of a map of the distribution of density $(\Delta \rho)$ at a depth of 1500 meters, is expected to inform some of the zones affected by the density $(\Delta \rho)$ ranging between $1.1 \mathrm{~g} / \mathrm{cc}-2.1 \mathrm{~g} / \mathrm{cc}$ in which the contours follow the pattern of the East Java basin showed a low density values to the north is occupied by a shallow sea sediment and tend to score higher density toward the South - Southeast is a volcanic sediment (volcano).

Keywords : Mud of Sidoarjo (LUSI), Monitoring, Gravity, Density

\section{Pendahuluan}

Luapan Lumpur Sidoarjo merupakan akibat dari aktivitas fluida (lumpur) bawah permukaan yang keluar melalui rekahan atau lubang-lubang. Hal ini dapat dilakukan melalui analisa karakteristik dari lumpur tersebut berdasarkan nilai rapat massanya. Kajian ini dilakukan melalui pengumpulan data gayaberat di daerah sekitar Lumpur Sidoarjo yang meliputi 3 Kecamatan yaitu Kecamatan Porong, Kecamatan Tanggulangin, dan Kecamatan Jabon, termasuk didalamnya beberapa desa terdampak yang cukup parah, seperti desa Siring Barat yang terletak di bagian Barat tanggul, desa Glagaharum di bagian Timur Tanggul, desa Kedungbendo dan desa Kalidawir di bagian Utara tanggul, dan dibagian Selatan tanggul adalah desa Kedungcangkring yang sampai bulan Juni 2011 masih belum diselesaikan masalah administrasinya oleh pihak BPLS. Tanggal 07 Februari 2011,

* email : e.supriyana@phys.unpad.ac.id 
Kementerian Energi dan Sumber Daya Mineral Republik Indonesia melalui BadanGeologi (No. 200/04/BGL/2011 Tanggal 26 Januari 2011) mengundang berbagai pihak Instansi maupun Institusi termasuk di dalamnya Perguruan Tinggi Unpad.

Terkait dengan kondisi struktur dan geometri di sekitar area tanggul Lumpur Sidoarjo termasuk di 3 kecamatan tersebut diprediksi sangat tidak stabil, dan berpotensi akan semburan gas atau bablebable, maka untuk mengeliminir hal-hal yang tidak diinginkan, digunakanlah metoda yang paling tepat yakni dengan menggunakan metoda gayaberat, yang sebelumnya sejak tahun 2009 sudah dilakukan penelitian dan monitoring menggunakan metoda gayaberat dengan spasi pengambilan data regional dan selanjutnya lebih dikembangkan lagi dengan spasi pengambilan datanya dirapatkan (spasi 50m) sehingga akan cukup efektif dalam memberikan informasi mengenai kondisi bawah permukaan yang beresolusi vertikal lebih baik, terutama di area dekat dengan tanggul lumpur. Permasalahannya adalah bagaimana melokalisir daerah-daerah terdampak LUSI berdasarkan analisis sebaran dan pergerakan lumpur bawah permukaan di sekitar 3 kecamatan tersebut.

Pengetahuan mengenai sebaran dan pergerakan massa lumpur di kedalaman $1500 \mathrm{~m}$ ini penting karena dengan pengetahuan tersebut diharapkan dapat memberi kontribusi berupa informasi kepada pemerintah pusat maupun pemda setempat didalam penanganan dampak bencana akibat luapan lumpur Porong di Kabupaten Sidoarjo.

Secara geologi daerah Porong, Sidoarjo merupakan bagian cekungan Jawa Timur yang tertutup oleh batuan sedimen yang berumur Kuarter sampai Halosen, dengan kedalaman mencapai 6000 meter, oleh karena itu kajian geologi daerah tersebut harus di korelasikan dengan study geofisika. Metoda gayaberat yang digunakan dalam penelitian ini dapat menjangkau kedalaman sampai \pm 3000 meter, dengan metoda ini dapat dilakukan analisis mengenai cekungan batuan alas, struktur geologi dan perkiraan arah perubahan massa dimana ketiga hal tersebut di atas, satu sama lainnya tidak dapat dipisahkan, ditambah dengan deformasi bawah permukaan yang mengkontrol munculnya tembusan gas maupun bualan air dan gas.

Dengan melalui penelitian ini dapat dilakukan analisis dan memprediksi kondisi struktur lapisan tanah dan pergerakan massa lumpur di bawah permukaan berdasarkan data gayaberat secara berkala (detail). Sehingga kemudian dapat memberikan gambaran mengenai perubahan massa yang berkaitan dengan luapan Lumpur Porong dan dikorelasikan dengan zona-zona struktur geologi yang kemungkinan teraktifkan adanya beban lumpur porong. Selain perubahan massa yang dapat terindikasi secara kualitatif juga dapat memperkirakan zona aliran lumpur bawah permukaan berdasarkan indikasi zona lemah atau penurunan rapat massa.

\section{Metode}

Dalam penelitian ini digunakan metode 4-D mikrogravity dimana titik-titik ukurnya berbentuk grid yang diukur dalam beberapa lapse, minimal dua lapse. Berdasarkan data pengukuran tiap lapse tersebut akan diperoleh sebaran $\Delta \mathrm{g}$ (perubahan/perbedaan nilai gayaberat) terhadap posisi dan waktu yang merepresentasikan sebaran $\Delta \rho$ berdasarkan fungsi Green, seperti pada persamaan (1). Sebagai dasar kajian untuk mengetahui adanya anomali gayaberat di bawah permukaan, diambil komponen vertikal gayaberat yakni dari persamaan yang dapat dituliskan sebagai berikut: 
$\Delta g_{z}(x, y, z)=G \int_{0}^{\infty} \int_{-\infty-\infty}^{\infty} \int_{[}^{\infty} \frac{\Delta \rho(\alpha, \beta, \gamma)(z-\gamma)}{\left[(x-\alpha)^{2}+(y-\beta)^{2}+(z-\gamma)^{2}\right]^{3 / 2}} d \alpha d \beta d \gamma$

Berdasarkan pengukuran secara berulang persamaan (1) menjadi :

$$
\Delta g(x, y, z, \Delta t)=-G \int_{0}^{\infty} \int_{-\infty-\infty}^{\infty} \int_{\infty}^{\infty} \frac{\Delta \rho(\alpha, \beta, \gamma, \Delta t)(z-\gamma)}{\left[(x-\alpha)^{2}+(y-\beta)^{2}+(z-\gamma)^{2}\right]^{3 / 2}} d \alpha . d \beta \cdot d \gamma \ldots \ldots . .(2)
$$

Dimana :

$$
\begin{array}{ll}
\Delta \mathrm{g} & =\text { perubahan gayaberat yang diamati } \\
\Delta \rho(\alpha, \beta, \gamma) & =\text { kontras rapat massa di bawah permukaan } \\
\mathrm{G} & =\text { konstanta gayaberat umum } \\
\mathrm{x}, \mathrm{y}, \mathrm{z} & =\text { titik koordinat yang diukur } \\
\Delta \mathrm{t} & =\text { Time-lapse }
\end{array}
$$

Berdasarkan nilai perubahan gayaberat $(\Delta \mathrm{g})$ yang diperoleh maka perubahan (pergerakan) rapat massa $\Delta \rho$ yang mengindikasikan adanya dinamika lumpur. Karena nilai $\Delta \mathrm{g}$ memiliki orde $\mu G a l$ maka digunakan microgravity. Pengukuran dilakukan dengan sistem loop tertutup pada titik-titik bench marks $(\mathrm{BM})$ pada waktu beberapa periode. Dari data tersebut maka akan diperoleh:

$$
\operatorname{gobs}(t 1) x y z-g o b s(t 2) x y z=\Delta g(x, y, z, \Delta t)
$$

Monitoring diartikan untuk memprediksi gerakan lumpur berdasarkan sifat fisik kondisi struktur batuan sebagai landasannya yaitu rapat massa. Gerakan tersebut dapat diamati melalui perubahan nilai gravitasi yang terukur pada waktu yang berbeda (time-lapse). Dalam penyelidikan ini membutuhkan waktu sekitar 25 hari untuk setiap lapse pengukuran. interval pengukuran antar lapse sekitar 3 bulan. Pengukuran gravitasi menggunakan gravimeter yang mempunyai spesifikasi peralatan sangat mudah operasional pengukurannya, hasil pengukuran akan langsung diperoleh nilai gravitasi absolutnya (satuan $m g a l$ ), dan tidak sampai ke perhitungan BA (Anomali Bouguer). Sedangkan pengukuran ketinggiannya digunakan GPS Leica yang mempunyai ketelitian sangat akurat.

Untuk satu kali pengukuran gravitasi presisi (microgravity) dan ketinggian dilakukan selama $\pm 3-4$ minggu pada titik BM yang mempunyai koordinat tetap (jika didukung dengan cuaca cerah dan posisi BM yang sudah jelas). Pengukuran tersebut dilakukan 3 kali pembacaan secara berulang pada lopping tertutup untuk masing-masing BM. Cara tersebut bertujuan untuk meminimalisir atau mengkoreksi apabila terjadi perubahan pembacaan yang cukup mencolok diantara inteval jarak BM tersebut. Selanjutnya data tersebut disusun dalam tabulasi sesuai waktu pengukuran, diplot dan dibuatkan peta kontur nilai gravitasi absolut sementara, yang bertujuan untuk melakukan cheking data yang telah dihimpun. Sehingga pada akhirnya akan diperoleh 2 atau 3 sebaran nilai delta medan gravitasi $(\Delta \mathrm{g})$ untuk dilakukan ke jenjang pengolahan gravitasi yang lebih detail sesuai dengan target penelitian.

Metodologi penelitian ini dikembangkan berdasarkan pada pengamatan visual lapangan seperti munculnya tembusan-tembusan gas dan tekanan air tanah, laporan laporan maupun peta geofisika atau geologi daerah Porong yang telah dipublikasikan. Pengukuran gayaberat dan elevasi mengacu 
pada pengukuran sebelumnya pada titik pengukuran yang sama dengan spasi 250 sampai 500 meter dan pada periode berikutnya lebih detail menjadi spasi 50 meter. Pengukuran gayaberat dilakukan secara looping tertutup, artinya pengukuran gayaberat di mulai dari titik pangkal lapangan dan kembali ke titik pangkal lapangan, Titik pengukuran ditempatkan pada lokasi yang stabil, mudah terjangkau dan mudah dikenal, yaitu halaman kantor kelurahan, sekitar mesjid, pertigaan jalan maupun sekitar jembatan. Penempatan titik pengamatan demikian akan digunakan untuk pengukuran secara priodik dan berfungsi sebagai monitoring gayaberat. Penambahan jumlah titik pengamatan kearah Kecamatan Sidoarjo, Sidokare dan Candi dimaksudkan untuk memperoleh gambaran struktur lebih luas kearah utara dan kemungkinan hubungannya dengan kondisi struktur bagian selatan.

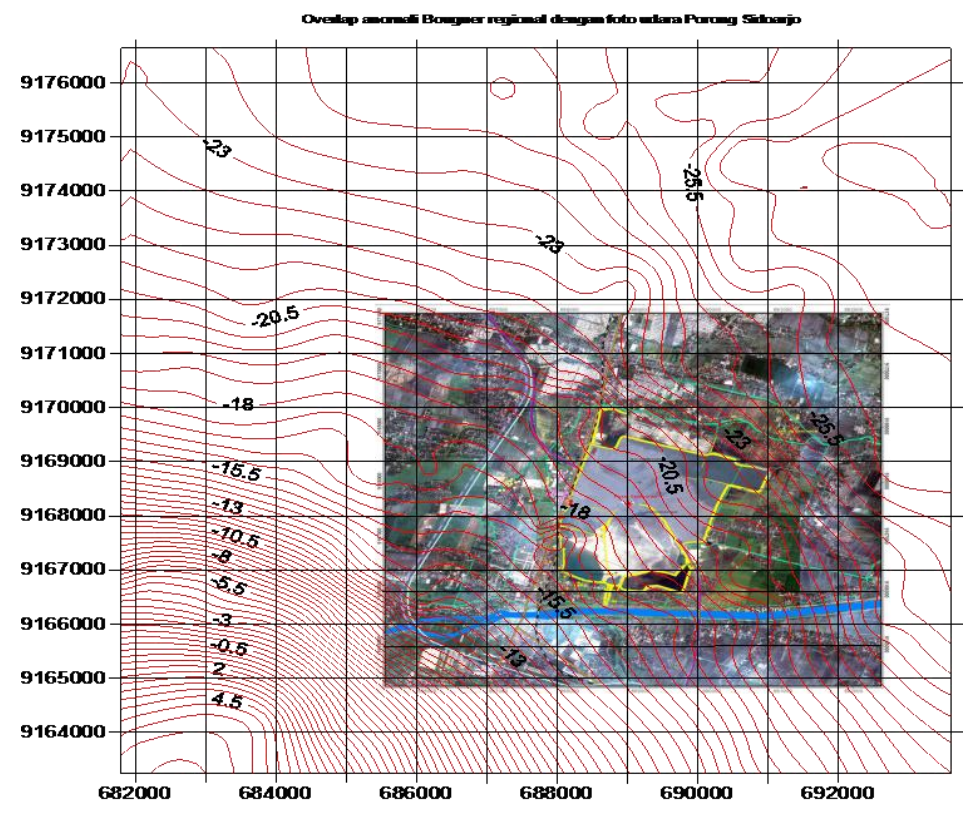

Gambar 1. Overlap Anomali Bouguer Regional dengan Foto Udara Porong Sidoarjo.

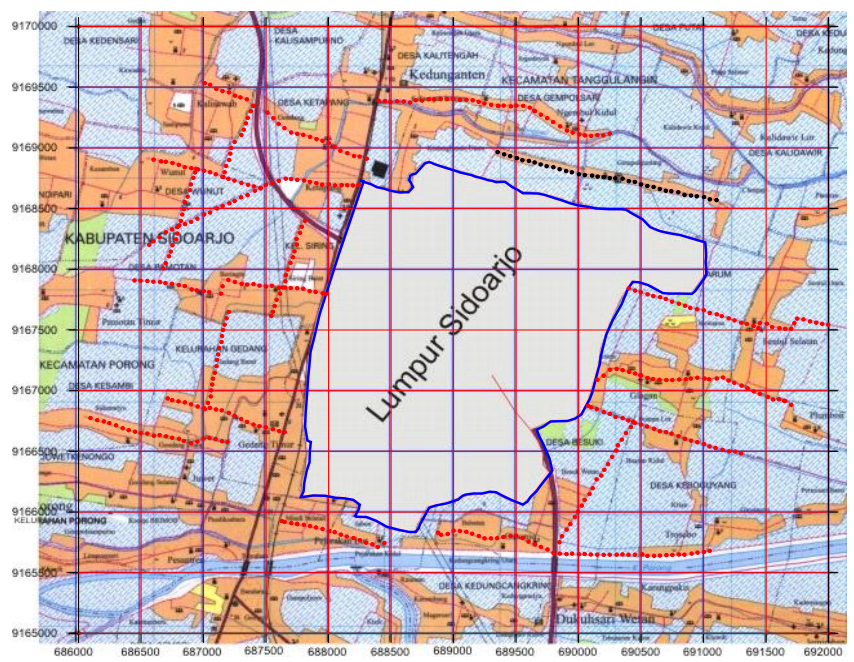

Gambar 2. Peta Titik Amat (•) Monitoring Gravity $( \pm>230$ ttk BM) di Sekitar Area LUSI (Perioda 2). 


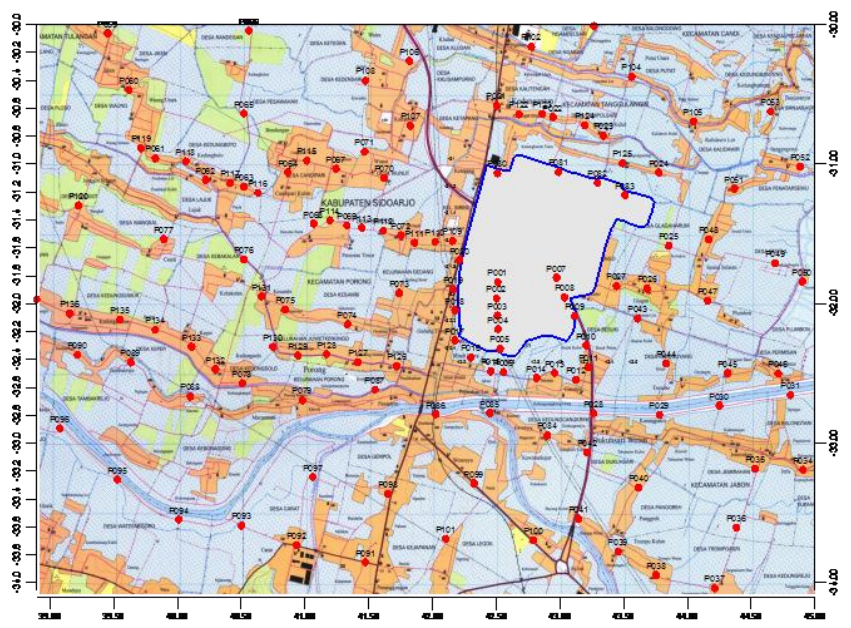

Gambar 3. Peta Titik Amat $(\bullet)$ Monitoring Gravity ( \pm 230 ttk BM) di Sekitar Area LUSI (Perioda 1)

Di sekitar lokasi yang tampak di peta pada gambar 2 dan 3 di atas kami melakukan survey dan membuat titik amat elevasi sebanyak \pm 230 titik amat pengukuran dengan menggunakan metoda gayaberat (Alliod) dan GPS Leica yang tersebar dengan radius $12 \mathrm{~km}$ dari pusat semburan lumpur termasuk di area padat perumahan penduduk.

\section{Hasil dan Pembahasan}

Pelaksanaan proses untuk sebaran nilai densitas diarahkan di kedalaman sekitar 1500 meter, diharapkan dapat melengkapi dan memberikan informasi terhadap penelitian sebelumnya bahwa di sekitar kedalaman antara 1000 meter - 2000 meter di area Lumpur Sidoarjo (LUSI) diduga sebagai sumber luapan lumpur yang bergerak ke arah sumur Banjar Panji 1 dan pusat semburan lumpur yang sampai dengan saat ini masih aktif.

Peta kontur sebaran densitas $(\rho)$ di kedalaman 1500 meter hasil proses ditampilkan dalam gambar 4, yang dicombine bersama sebaran titik amat gravity, peta wilayah beberapa kecamatan, dan desa terdampak luapan lumpur Sidoarjo (LUSI).

Berdasarkan sebaran nilai densitas yang diperoleh berkisar dari 1,1 gr/cc - 2,1 gr/cc dengan kontur mengikuti pola cekungan Jawa Timur yang menunjukan nilai densitas rendah ke arah Utara yang ditempati oleh endapan laut dangkal dan cenderung nilai densitas tinggi menuju ke arah Selatan Tenggara yang merupakan endapan volkanik (gunungapi).

Nilai densitas 1,8 gr/cc berada di posisi dekat pusat semburan lumpur di dalam tanggul, diduga sebagai material lumpur yang terakumulasi dari berbagai endapan yang mendapat tekanan dari arah Baratlaut (Siring Barat). Bila dikorelasikan dengan hasil pengamatan di permukaan di sekitar area Siring Barat, Gedang dan Tanggulangin terhadap sebaran nilai densitas yang tampak dipeta sebarannya bahwa di ketiga area tersebut ditemukan adanya bualan air atau gas dan amblasan, sehingga dapat diduga dengan besarnya nilai rapat massa : $1,10 \mathrm{gr} / \mathrm{cc}-1,75 \mathrm{gr} / \mathrm{cc}$ adalah merupakan nilai densitas air atau lumpur yang mengalami pergerakan massa dan tekanan melalui kanal sesar menuju ke arah luapan LUSI sehingga area tersebut mengalami pengosongan pore space bawah permukaan yang merupakan penyebab terjadinya amblasan. 


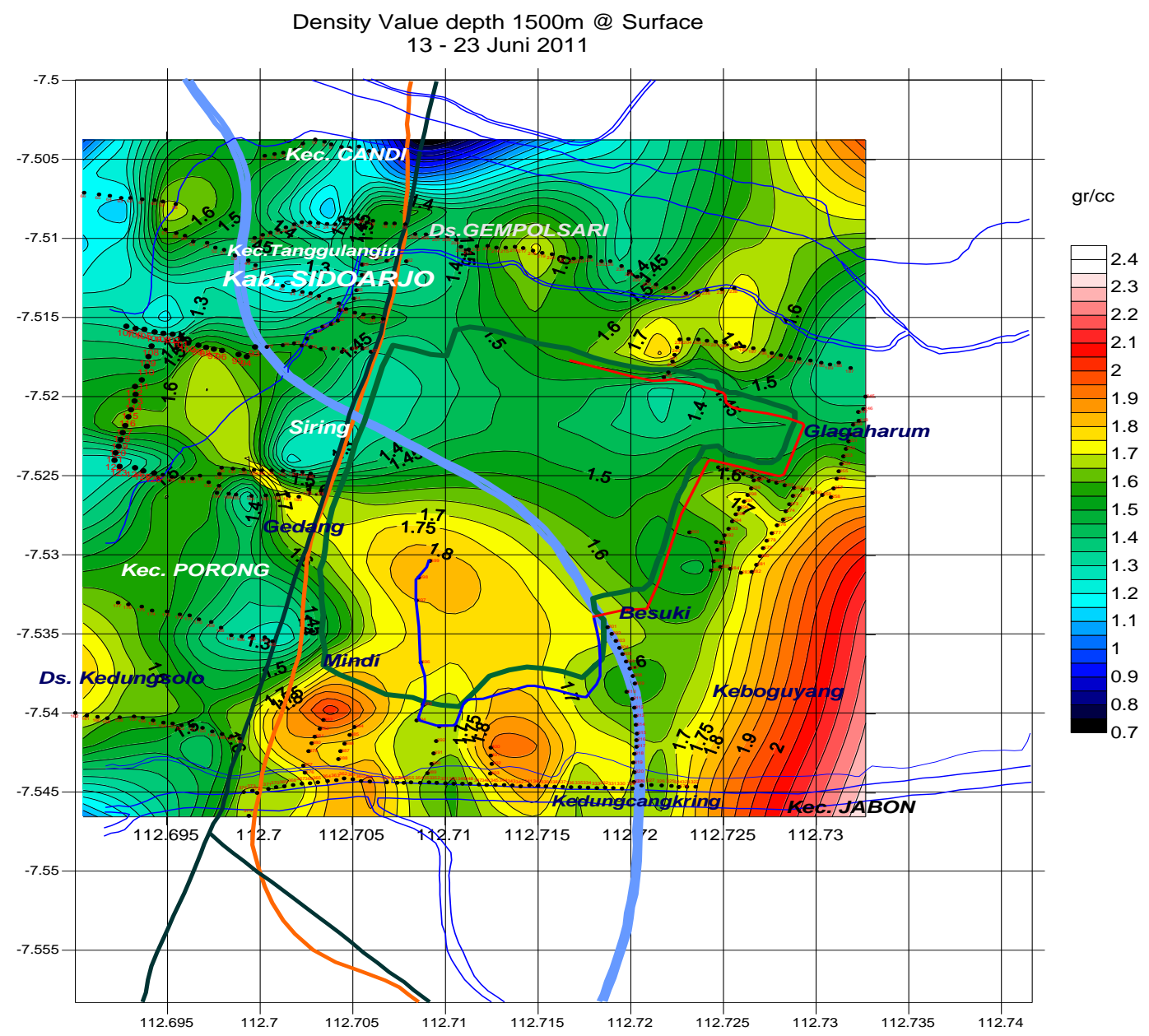

Gambar 4. Peta sebaran densitas di kedalaman $1500 \mathrm{~m}$, combine dengan sebaran titik amat gravity, peta wilayah beberapa kecamatan, dan desa terdampak luapan lumpur Sidoarjo (LUSI).

Berdasarkan hasil interpretasi Gambar 4 dapat diperoleh beberapa area yang diduga sebagai berikut:

A. Bagian Barat tanggul LUSI, zona tidak stabil dan rawan amblas yakni :

1. Siring Barat dengan sebaran nilai rapat massa : $1,1 \mathrm{gr} / \mathrm{cc}-1,7 \mathrm{gr} / \mathrm{cc}$

2. Kec. Tanggulangin dengan sebaran nilai rapat massa : 1,25 gr/cc $-1,60 \mathrm{gr} / \mathrm{cc}$.

3. Desa Gedang dengan sebaran nilai rapat massa : $1,30 \mathrm{gr} / \mathrm{cc}-1,70 \mathrm{gr} / \mathrm{cc}$.

4. Mindi bagian Utara denga sebaran nilai rapat massa : $1,30 \mathrm{gr} / \mathrm{cc}-1,50 \mathrm{gr} / \mathrm{cc}$

Diprediksi zona ini mempunyai potensi adanya bualan air dan gas atau lumpur yang pergerakan massanya menerobos melalui kanal / sesar menuju ke pusat semburan.

B. Bagian Utara tanggul LUSI, di sekitar Desa Gempolsari, yang mempunyai potensi endapan lumpur dan amblasan dengan indikasi penurunan sebaran nilai rapat massa 1,50 gr/cc - 1,75 gr/cc, zona ini relatif tidak menampakan memberikan kontribusi pergerakan lumpur ke arah luapan lumpur di dalam tanggul, diduga ada buffer berupa sesar juga linement serarah Baratlaut - Tenggara. 
C. Bagian Timur - Tenggara tanggul LUSI, di sekitar Desa Glagaharum, Desa Besuki dan Desa Keboguyang, yang mempunyai potensi endapan lumpur dengan sebaran nilai rapat massa : $1,60 \mathrm{gr} / \mathrm{cc}-2,1 \mathrm{gr} / \mathrm{cc}$, zona relatif stabil, dan diduga ada buffer sehingga potensi lumpur tidak bergerak ke arah tanggul lumpur, hal tersebut didukung dengan adanya pola penekukan maupun pergeseran atau offset yang dipengaruhi oleh struktur geologi dan mungkin juga teraktivasi yang disebabkan adanya beban lumpur karena terletak di lereng Jawa Timur.

D. Bagian Selatan tanggul LUSI, di sekitar Desa Kedungcangkring, Kecamatan Jabon dan kali Porong, merupakan zona yang mempunyai potensi lumpur terakumulasi dengan luapan LUSI, hanya dibeberapa area (Mindi Selatan dan Babatan) diduga masih mempunyai Buffer yang relatif dapat menstabilkan struktur dengan nilai rapat massa tinggi yakni : 1,90 gr/cc $-2,10$ $\mathrm{gr} / \mathrm{cc}$. yang diduga merupakan endapan volkanik dari gunung Penanggungan

\section{Kesimpulan}

Berdasarkan hasil analisis sebaran nilai rapat massa menunjukkan bahwa ada zona lemah di bagian Barat /Utara dan zona kuat di bagian Selatan. Dimana zona lemah tersebut mencapai kedalaman sampai 1500 meter. Zona lemah tersebut menerus sampai ke daerah Siringbarat dan Tanggulangin. Sementara keberadaan zona kuat berada di bagian Selatan yang ditunjukkan oleh kekuatan lintasan Jalan Tol Porong yang tidak mengalami retakan maupun kerusakan jalan. Sehingga berdasarkan analisis rapat massa $(\rho)$ tersebut dapat memberikan gambaran bahwa lokasi ke arah Selatan kolam Lumpur Sidoarjo diduga relatif stabil.

\section{Ucapan terima kasih}

Dengan selesainya penelitian ini penulis tidak lupa mengucapkan terima kasih yang sebesarbesarnya, kepada teman-teman di Pusat Survey Geologi (PSG), Badan Geologi Bandung dan Kementerian Energi dan Sumberdaya Mineral (ESDM) Jakarta yang telah bekerjasama dalam penelitian ini.

\section{Daftar Pustaka}

1. Antonio, G. Camacho, et al., 1999, Gravity Inversion by Means of Growing Bodies, Jurnals Geophysics, Vol. 65 No. 1, p. $95-101$.

2. Blakely, R.J., 1995, Potential Theory in Gravity \& Magnetic Application, Cambridge University Press.

3. Hare, J.L., Fergusson, J.F., Aiken, C.L.V., Brady, J.L., 1999, The 4-D Microgravity Method for Waterflood Surveillance : A Model Study for The Prudhoe Bay Reservoir, Alaska, Geophysics, Vol. 64 No. 1.

4. Kadir, W.G.A., 1999, Survey Medan gravitasi 4 Dimensi dan Dinamika Sumber Bawah Permukaan; Suatu Pendekatan Teoritis, Proceeding HAGI XXIV, Surabaya.

5. Supriyana, E., 2004, Estimasi Distribusi Rapat Massa dan Saturasi Air Berdasarkan Anomali Mikrograviti 4D dan Applikasinya Untuk Daerah Geothermal Kamojang-Garut, Thesis Magister Program Pascasarjana UI..

6. Schön, J.H., 1996, Seismic Exploration, Physical Properties of Rocks; Fundamentals Theory and Principles of Petrophysics, Pergamon, Vol. 18. 